\title{
Characterization Plan and Dissolution Tests for Tank 16H Samples
}

by

P. L. Davis

Westinghouse Savannah River Company

Savannah River Site

Aiken, South Carolina 29808

M. S. Hay

not a conf

A document prepared for TANK FOCUS AREA MID-YEAR REVIEW at Salt Lake City, UT, USA from -

DOE Contract No. DE-AC09-96SR18500

This paper was prepared in connection with work done under the above contract number with the U.S.

Department of Energy. By acceptance of this paper, the publisher and/or recipient acknowledges the U.S. Government's right to retain a nonexclusive, royalty-free license in and to any copyright covering this paper, along with the right to reproduce and to authorize others to reproduce all or part of the copyrighted paper. 


\section{DISCLAIMER}

This report was prepared as an account of work sponsored by an agency of the United States Government. Neither the United States Government nor any agency thereof, nor any of their employees, makes any warranty, express or implied, or assumes any legal liability or responsibility for the accuracy, completeness, or usefulness of any information, apparatus, product, or process disclosed, or represents that its use would not infringe privately owned rights. Reference herein to any specific commercial product, process, or service by trade name, trademark, manufacturer, or otherwise does not necessarily constitute or imply its endorsement, recommendation, or favoring by the United States Government or any agency thereof. The views and opinions of authors expressed herein do not necessarily state or reflect those of the United States Government or any agency thereof.

This report has been reproduced directly from the best available copy.

Available to DOE and DOE contractors from the Office of Scientific and Technical Information, P.O. Box 62, Oak Ridge, TN 37831; prices available from (615) 576-8401.

Available to the public from the National Technical Information Service, U.S. Department of Commerce, 5285 Port Royal Road, Springfield, VA 22161. 


\section{DISCLAIMER}

Portions of this document may be illegible electronic image products. Images are produced from the best available original document. 


\title{
WESTINGHOUSE SAVANNAH RIVER COMPANY SAVANNAH RIVER TECHNOLOGY CENTER
}

\author{
Keywords: Waste Removal \\ Sludge Analysis \\ Supernate Analysis
}

WSRC-RP-98-00032

$\begin{array}{ll}\text { Distribution: } & \text { W. L. Tamosaitis, 773-A } \\ & \text { S. D. Fink, 773-A } \\ \text { B. T. Butcher, 773-43A } \\ \text { T. M. Monahon, 703-H } \\ \text { P. D. D'Entremont, 703-H } \\ \text { B. L. Lewis, 703-H } \\ \text { E. Saldivar, 742-4G } \\ \text { B. A. Martin, 742-4G } \\ \text { T. B. Caldwell, 742-4G } \\ \text { J. L. Newman, 703-H } \\ \text { R. K. Cauthen, 704-S } \\ \text { J. R. Cook, 773-43A } \\ \text { C. A. Langton, 773-43A } \\ \text { V. G. Dickert, 703-H } \\ \text { TIMS (4) }\end{array}$

FROM: M. S. HAY, 773-A meRf

\section{Characterization Plan and Dissolution Tests for Tank 16H Samples}

\section{Summary}

In support of the closure of Tank $16 \mathrm{H}$, a sample of the solids residue on the bottom of the tank interior and three samples from the tank annulus will be sent to SRTC for analysis. ${ }^{1}$ The results of the analysis of the samples from the tank interior and the annulus will define the source term inventory used for fate and transport modeling. In addition, the samples from the tank annulus will be used for dissolution tests to evaluate the effectiveness of various cleaning alternatives.

\section{Characterization}

A portion of each of the four samples from Tank $16 \mathrm{H}$ will be dried and digested by a minimum of two different methods. Each digestion will be done in triplicate. The digested solids samples will be diluted with deionized, distilled water prior to analysis. The diluted digestion sample will be analyzed for the species listed in the Table 1. Provided there is greater than $10 \mathrm{~g}$ of solids for each sample, a small portion of the dried solids of each sample will be contacted with a $0.01 \mathrm{M} \mathrm{NaOH}$ solution (inhibited water) to analyze for the soluble species listed in Table 1. Other analyses will be conducted 
as needed to determine the chemical composition of the samples. This work has been requested by a Technical Task Request. ${ }^{2}$

\section{Salt Dissolution Tests}

The samples from the tank annulus will be used to study methods for dissolving the material contained in the tank annulus. If the characterization of the annulus samples indicates the samples have essentially the same composition, the samples with similar compositions will be combined to make a composite sample. Samples with distinctly different compositions will be treated individually. Five variables will be controlled in the dissolution tests to simulate expected Tank $16 \mathrm{H}$ conditions and capabilities; the dissolution reagent, the volume of dissolution reagent, the temperature, the contact time between the reagent and the solids, and the amount of mixing. Mixing will be minimized by pouring the reagent onto the solids and allowing the mixture to sit undisturbed. Qualitative assessments of the amount of dissolution of the solids as a function of contact time will be made at periodic intervals up to 48 hours. Dissolution tests with each of the reagents will be conducted at ambient temperature and $60^{\circ} \mathrm{C}$. A minimal volume of the dissolution reagent, approximately $3 X$ the volume of the solids, will be used in the tests. The following dissolution reagents will be used in the tests:

\footnotetext{
- $\quad 3 \mathrm{M} \mathrm{NaOH}$ at ambient temperature and $60^{\circ} \mathrm{C}$

- Inhibited Water $(0.01 \mathrm{M} \mathrm{NaOH})$ at ambient temperature and $60^{\circ} \mathrm{C}$

- $\quad$ Process Water at ambient temperature and $60^{\circ} \mathrm{C}$

- $4 \mathrm{wt} \%$ Oxalic Acid at ambient temperature and $60^{\circ} \mathrm{C}$.
}

The general procedure for the dissolution tests will be to place a weighed amount of the composite sample in a polysulfone (clear plastic) centrifuge tube. A minimal volume of the dissolution reagent (approximately $3 X$ the volume of the solids) will be added to the centrifuge tube with minimal mixing. For tests run at $60^{\circ} \mathrm{C}$, the reagent will be heated to $60^{\circ} \mathrm{C}$ and added to the centrifuge tube with no further heating of the tube to simulate plant capabilities. Estimates of the amount of dissolution will be made hourly by visual inspection. The tubes will be gently mixed after 48 hours if the dissolution with no mixing was minimal. The tubes will be centrifuged and the solution decanted from any remaining solids. Centrifuges tubes containing solids after the first contact with the reagent will be contacted with the reagent a second time for 48 hours. At the end of the dissolution tests, any remaining solids in the centrifuge tubes will be sealed in the tubes (after decanting) and stored in case further characterization of these solids is required. Dissolution tests in which all of the solids have dissolved may be terminated prior to 48 hours.

\section{References}

1. J. Newman, "Sampling Plan to Support HLW Tank 16", WSRC-TR-97-00350, October 30, 1997.

2. Technical Task Request HLE-TTR-98014. 
W. E. Stevens

WSRC-RP-98-00032

Page 3 of 5

Table 1. Characterization of Tank $16 \mathrm{H}$ Samples

\begin{tabular}{|c|c|c|c|}
\hline Element & Method & $\begin{array}{c}\text { Analysis of } \\
\text { Total Dried } \\
\text { Solids }\end{array}$ & $\begin{array}{l}\text { Analysis of } \\
\text { Inhibited Water } \\
\text { Soluble Fraction }\end{array}$ \\
\hline $\mathrm{Cs}^{137}$ & Gamma counting & $\sqrt{ }$ & \\
\hline $\mathrm{Sr}^{90}$ & Liquid Scintillation & $\sqrt{ }$ & \\
\hline $\mathrm{Tc}^{99}$ & Liquid Scintillation & $\sqrt{ }$ & \\
\hline $\mathrm{Se}^{79}$ & Liquid Scintillation & $\sqrt{ }$ & \\
\hline $\mathrm{Pu}^{238}$ & ICP-MS/Alpha PHA & $\sqrt{ }$ & \\
\hline $\mathrm{Pu}^{239}$ & ICP-MS & $\sqrt{ }$ & \\
\hline $\mathrm{Pu}^{241}$ & ICP-MS/Gamma & $\sqrt{ }$ & \\
\hline $\mathrm{Am}^{241}$ & Gamma counting & $\sqrt{ }$ & \\
\hline $\mathrm{Ag}$ & ICP-ES/ICP-MS & $\sqrt{ }$ & \\
\hline As & ICP-ES & $\sqrt{ }$ & \\
\hline $\mathrm{Se}$ & ICP-ES & $\sqrt{ }$ & \\
\hline $\mathrm{Ca}$ & ICP-ES & $\sqrt{ }$ & $\sqrt{ }$ \\
\hline $\mathrm{Cd}$ & ICP-ES & $\sqrt{ }$ & $\checkmark$ \\
\hline $\mathrm{Ce}$ & ICP-ES & $\sqrt{ }$ & \\
\hline Co & ICP-ES & $\sqrt{ }$ & $\sqrt{ }$ \\
\hline $\mathrm{Cu}$ & ICP-ES & $\sqrt{ }$ & $\sqrt{ }$ \\
\hline $\mathrm{Mg}$ & ICP-ES & $\sqrt{ }$ & $\sqrt{ }$ \\
\hline $\mathrm{Mn}$ & ICP-ES & $\sqrt{ }$ & $\sqrt{ }$ \\
\hline $\mathrm{Pb}$ & ICP-ES & $\sqrt{ }$ & $\sqrt{ }$ \\
\hline $\mathrm{Zn}$ & ICP-ES & $\sqrt{ }$ & $\sqrt{ }$ \\
\hline $\mathrm{Zr}$ & ICP-ES & $\sqrt{ }$ & $\sqrt{ }$ \\
\hline $\mathrm{Al}$ & ICP-ES & $\checkmark$ & $\checkmark$ \\
\hline $\mathrm{Ba}$ & ICP-ES & $\sqrt{ }$ & $\sqrt{ }$ \\
\hline
\end{tabular}

$\checkmark$ indicates the analyses that will be completed for each type of sample 
W. E. Stevens

WSRC-RP-98-00032

Page 4 of 5

Table 1. (Continued)

\begin{tabular}{|c|c|c|c|}
\hline Element & Method & $\begin{array}{l}\text { Analysis of } \\
\text { Total Dried } \\
\text { Solids }\end{array}$ & $\begin{array}{l}\text { Analysis of } \\
\text { Inhibited Water } \\
\text { Soluble Fraction }\end{array}$ \\
\hline $\mathrm{Fe}$ & ICP-ES & $\sqrt{ }$ & $\sqrt{ }$ \\
\hline $\mathrm{La}$ & ICP-ES & $\checkmark$ & $\sqrt{ }$ \\
\hline $\mathrm{Li}$ & ICP-ES & $\checkmark$ & $\sqrt{ }$ \\
\hline Mo & ICP-ES & $\sqrt{ }$ & $\sqrt{ }$ \\
\hline $\mathrm{Na}$ & ICP-ES & $\sqrt{ }$ & $\sqrt{ }$ \\
\hline $\mathrm{Ni}$ & ICP-ES & $\checkmark$ & $\sqrt{ }$ \\
\hline Sn & ICP-ES & $\checkmark$ & $\checkmark$ \\
\hline $\mathrm{Sr}$ & ICP-ES & $\sqrt{ }$ & $\sqrt{ }$ \\
\hline $\mathrm{Ti}$ & ICP-ES & $\sqrt{ }$ & $\sqrt{ }$ \\
\hline V & ICP-ES & $\sqrt{ }$ & $\checkmark$ \\
\hline$B$ & ICP-ES & $\sqrt{ }$ & $\sqrt{ }$ \\
\hline $\mathrm{Cr}$ & ICP-ES & $\sqrt{ }$ & $\sqrt{ }$ \\
\hline $\mathrm{P}^{-5}$ & ICP-ES & $\sqrt{ }$ & $\sqrt{ }$ \\
\hline $\mathrm{Si}$ & ICP-ES & $\sqrt{ }$ & $\sqrt{ }$ \\
\hline $\mathrm{Hg}$ & $A A C V$ & $\sqrt{ }$ & \\
\hline flouride & IC scan & & $\checkmark$ \\
\hline chloride & IC scan & & $\checkmark$ \\
\hline nitrate & IC scan & & $\sqrt{ }$ \\
\hline nitrite & IC scan & & $\checkmark$ \\
\hline oxalate & IC scan & & $\checkmark$ \\
\hline sulfate & IC scan & & $\sqrt{ }$ \\
\hline carbonate & titration & & $\checkmark$ \\
\hline
\end{tabular}

$\checkmark$ indicates the analyses that will be completed for each type of sample 
W. E. Stevens

WSRC-RP-98-00032

Page 5 of 5

Approvals

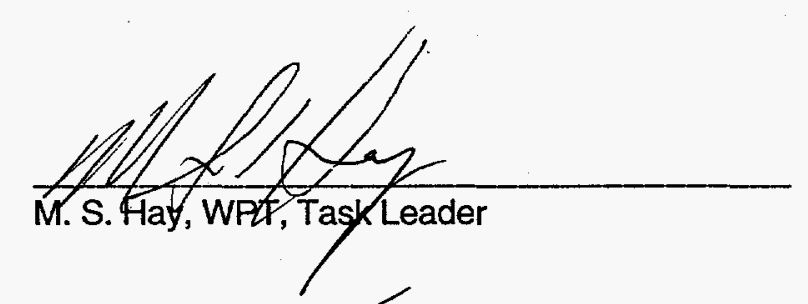

$\frac{2 / 9 / 98}{\text { Date }}$
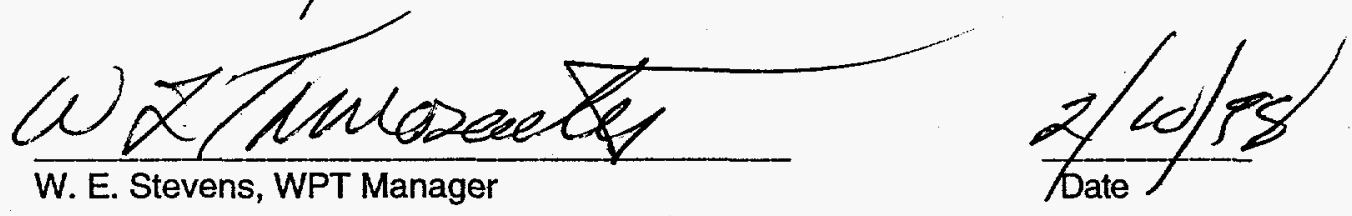

Glustime A bencher

C. A. Langton, WPT, Design g heck

$\frac{2 / 9 / 98}{\text { Date }}$ 